
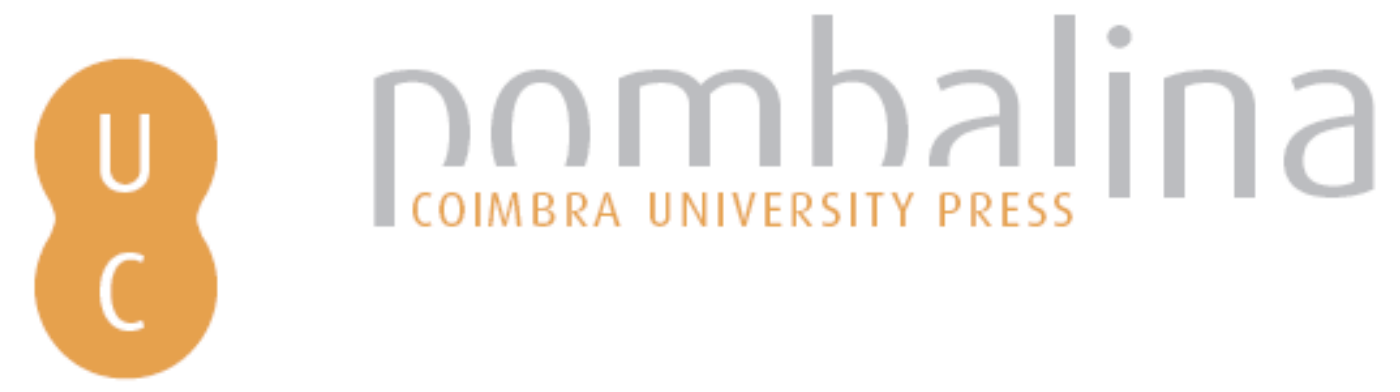

\title{
Global mapping of burned areas from European satellites: the fire_cci project
}

Autor(es): $\quad$ Chuvieco, Emilio; Alonso-Canas, Itziar; Padilla, Marc; Ramo, Ruben

Publicado por: Imprensa da Universidade de Coimbra

URL

persistente: URI:http://hdl.handle.net/10316.2/34314

DOI: $\quad$ DOI:http://dx.doi.org/10.14195/978-989-26-0884-6_87

Accessed : $\quad$ 26-Apr-2023 13:45:59

A navegação consulta e descarregamento dos títulos inseridos nas Bibliotecas Digitais UC Digitalis, UC Pombalina e UC Impactum, pressupõem a aceitação plena e sem reservas dos Termos e Condições de Uso destas Bibliotecas Digitais, disponíveis em https://digitalis.uc.pt/pt-pt/termos.

Conforme exposto nos referidos Termos e Condições de Uso, o descarregamento de títulos de acesso restrito requer uma licença válida de autorização devendo o utilizador aceder ao(s) documento(s) a partir de um endereço de IP da instituição detentora da supramencionada licença.

Ao utilizador é apenas permitido o descarregamento para uso pessoal, pelo que o emprego do(s) título(s) descarregado(s) para outro fim, designadamente comercial, carece de autorização do respetivo autor ou editor da obra.

Na medida em que todas as obras da UC Digitalis se encontram protegidas pelo Código do Direito de Autor e Direitos Conexos e demais legislação aplicável, toda a cópia, parcial ou total, deste documento, nos casos em que é legalmente admitida, deverá conter ou fazer-se acompanhar por este aviso.

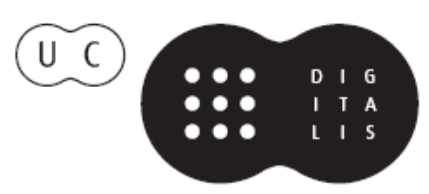




\section{ADVANCES IN}

Forest Fire

\section{RESEARCH}

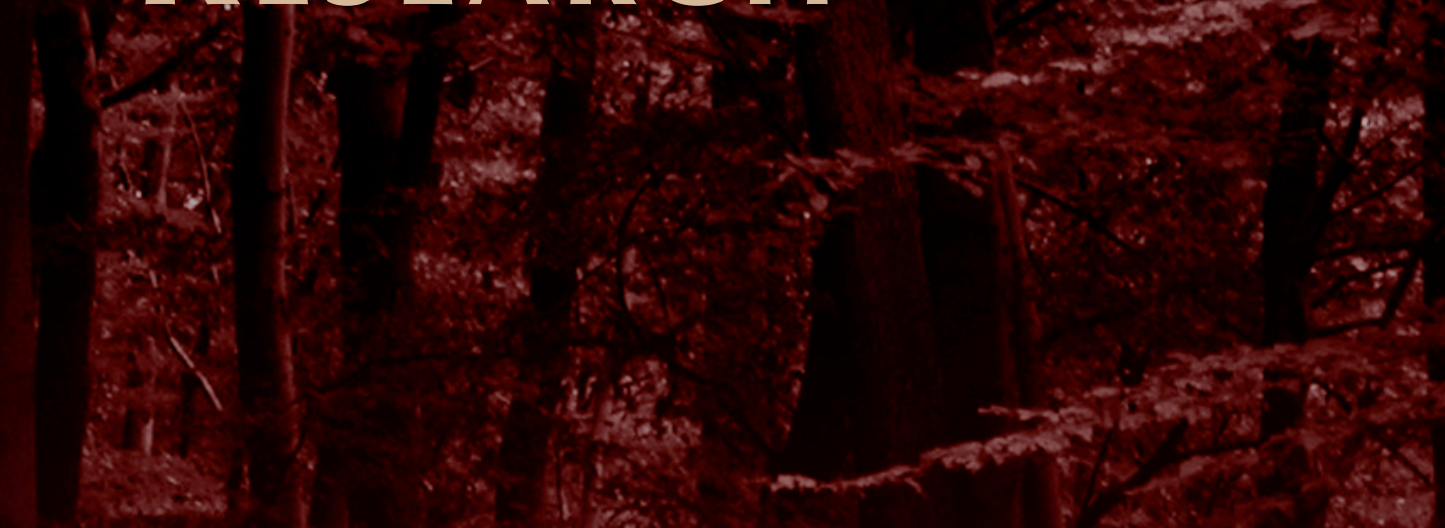

\section{DOMINGOS XAVIER VIEGAS}

\section{EDITOR}




\title{
Global mapping of burned areas from European satellites: the fire_cci project
}

\author{
Emilio Chuvieco, Itziar Alonso-Canas, Marc Padilla and Ruben Ramo
}

Environmental Remote Sensing Research Group, Universidad de Alcalá, Colegios 2, Alcalá de Henares, Spain; emilio.chuvieco@uah.es

\begin{abstract}
This paper presents the results of phase 1 of the fire_cci project. This project is part of the Climate Change Initiative of the European Space Agency, and aims to generate global, long-term burned area maps from European sensors (VEGETATION and MERIS). This information is intended to help modelling efforts of climate and atmospheric and carbon scientists, by adjusting to their needs in terms of product specifications. The project has done an extensive effort of validation and error characterization of the results. Intercomparison with other existing datasets has also been carried out.
\end{abstract}

Keywords: Burned area, Remote Sensing, Climate Change Initiative, GCOS, Earth Observation

\section{Introduction}

The European Space Agency (ESA) Climate Change Initiative (CCI) is part of the European contribution to the Global Climate Observing System (GCOS) program. The CCI aims to produce consistent and accurate time series of Essential Climate Variables (ECV), which may be used by climate, atmospheric and ecosystem scientists for their modelling efforts Plummer 2009. The CCI stresses the importance of improving scientific impact of data acquired by ESA sensors, while maintain close links with key science bodies and other agencies currently generating ECV data. The first call of the CCI program has included 13 ECVs covering atmospheric products (ozone, greenhouse gasses, aerosols andclouds), oceanic variables (ocean colour, sea ice, ocean height and temperature), and terrestrial (fire, glaciers, ice sheets, soil moisture and land cover): http://www.esa-cci.org/.

Biomass burning is widely recognized as one of the critical factors affecting vegetation succession and carbon budgets worldwide (Chuvieco 2008; Thonicke et al. 2010). At regional and local scale, fires have also important socio-economic implications, both affecting lives and structures (Chuvieco et al. 2010). At a global scale, the effects of fire on the atmospheric chemistry, both in terms of CO2 and aerosols emissions are very relevant (Bowman et al. 2009; van der Werf et al. 2010). The most recent studies estimate that an average area of 3.5 million $\mathrm{km} 2$ is burned every year (Giglio et al. 2010; Tansey et al. 2008), mostly in the Tropical savannahs, temperate grasslands and boreal forests. Other impacts of fire on the global climate are still poorly understood, such as the direct and indirect role of aerosols, their impact on land use change and surface albedo, the relation with tropospheric ozone and the deposition of black carbon on soils (Bowman et al. 2009).

The fire_cci project aims to improve mapping of burned areas (BA), including proper validation and error characterization, as well as the use of BA information in global vegetation and atmospheric models. The fire-cci project has been developed by a consortium of ten teams from five different European countries: University of Alcalá, CIFOR-INIA and GMV (Spain); GAF, DLR and Julich (Germany), IRD and LSCE-CEA (France), ISA (Portugal), and University of Leicester (UK). These groups cover the different specialities required for the project: Earth Observation scientists, Climateatmospheric-vegetation modellers and System engineers. 


\section{Methods}

Figure 1 includes the general flowchart of the fire_cci project. The project started with the definition of user requirements, which guided the generation of product specifications. The Burned Area (BA) product was initially based on the analysis of ERS and ENVISAT-ATSR, SPOT VEGETATION (VGT) and ENVISAT MERIS sensors, although finally the ATSR datasets were discarded as they did not provide significant improvement over VGT data. The project included geometric and radiometric corrections, masks, BA and merging algorithms (to fuse BA results from VGT and MERIS sensors), as well as validation and intercomparison analysis.

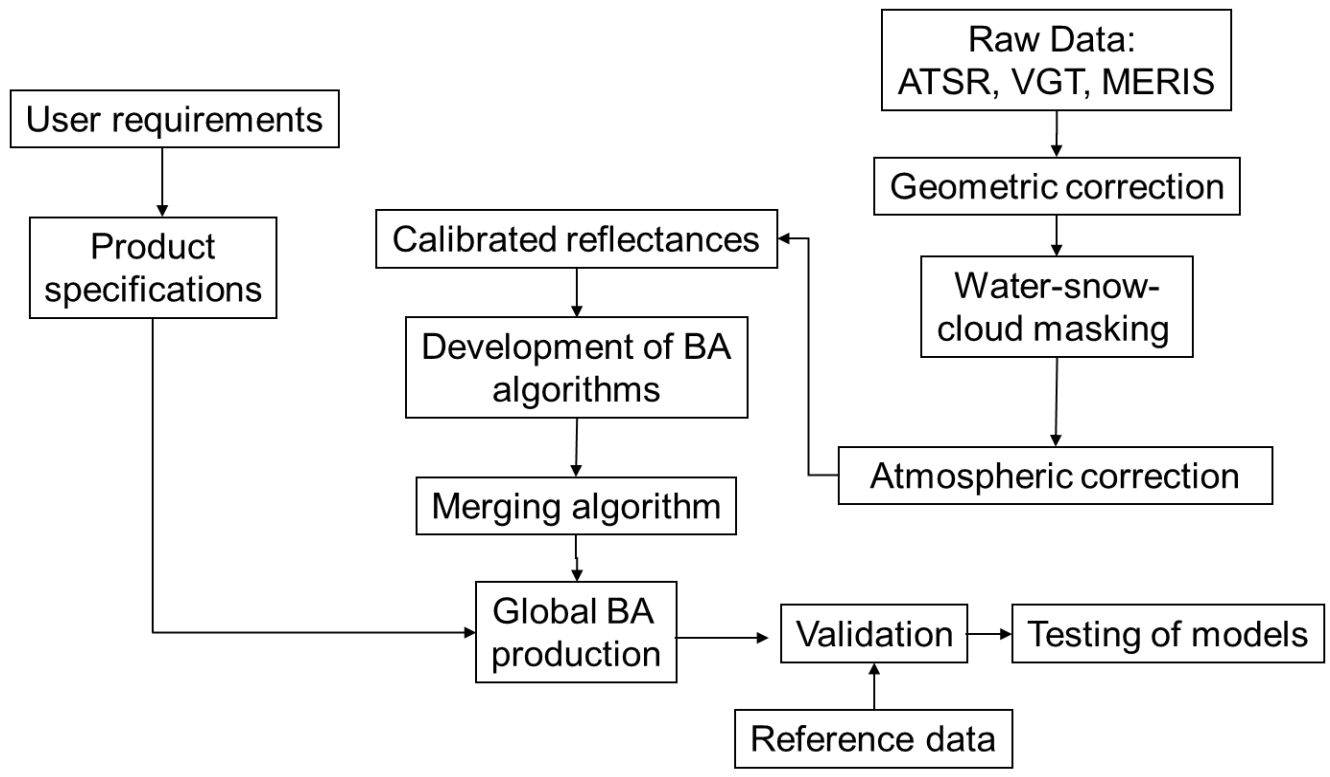

Figure 1. Fire_cci project flowchart

\subsection{User requirements and product specifications}

A proper understanding of user requirements of any product is a critical step to assure that the product will benefit the target community. In the case of the CCI program, the definition of user requirements was part of the program strategy. For the fire_cci project, a detailed questionnaire was addressed to potential users. Forty seven scientists from different fire-related communities (modellers, remote sensing experts, natural hazards, forestry sector...) provided their answers. They were complemented by an extensive literature review on past and present uses of available burned area (BA) products (Mouillot et al. 2014).

From this analysis, the product specifications (PSD) were generated. The fire_cci project includes two BA products, one at pixel level at $300 \mathrm{~m}$ resolution, and the other one at grid level at 0.5 degree resolution, following the most standard climate grid modelling (CGM) size). The pixel product includes four variables: day of burned detection, confidence level, sensor detecting the burn, and burned land cover. It will be distributed in monthly Geotiff format files, dividing the world in six tiles to make files more manageable (Figure 2). These tiles were agreed with the landcover_cci project to facilitate across-product consistency. The grid product includes 22 layers: sum of BA for each cell, standard error, fraction of observed area in the period, number of burn patches and burned area of each land cover (derived from globcover2005:Arino et al. 2007). These grid BA files are produced for 15day periods in NetCDF format. Both pixel and grid products use the Plate Carre projection and geographical coordinates. 


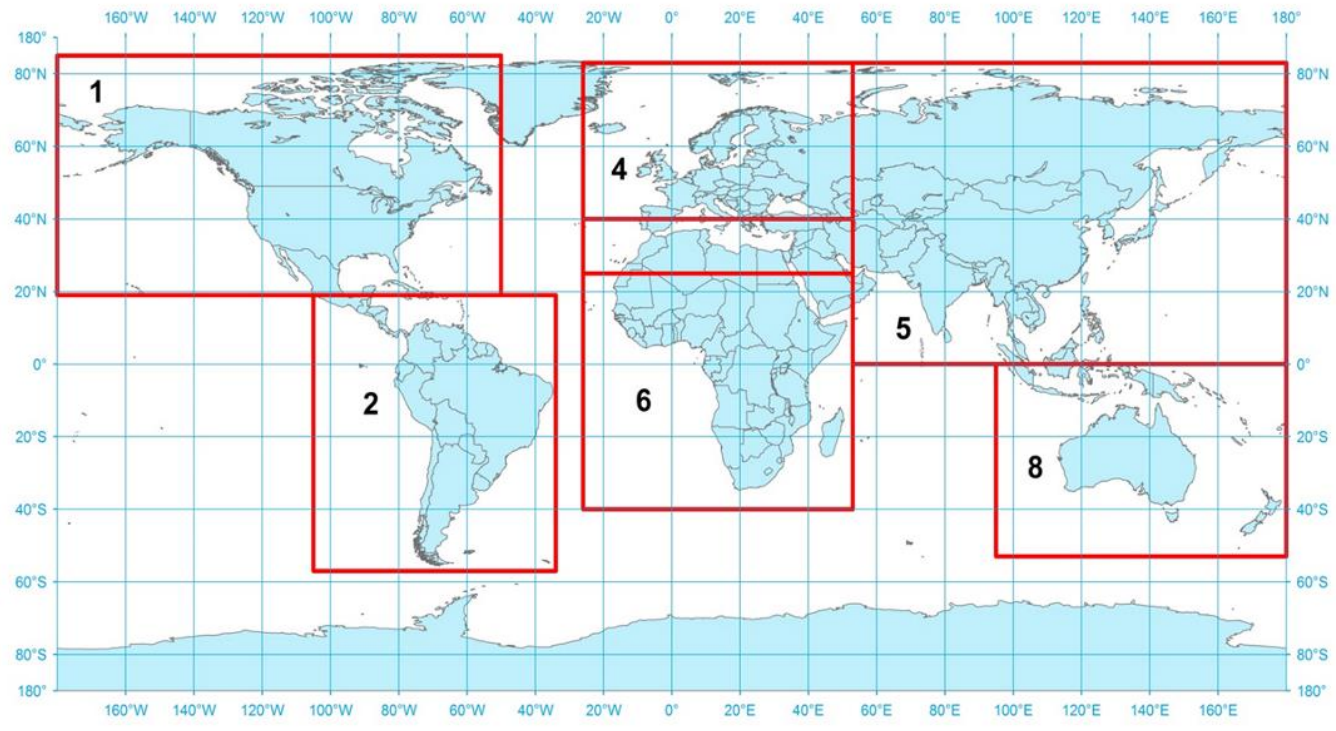

Figure 2. Tiles for the fire_cci pixel project

\subsection{Pre-processing}

The pre-processing, the BA products of the fire_cci project was based on level-1B and level-2 calibrated radiances from VEGETATION and MERIS. To derive corrected level 2 products, advanced image geometrical matching was applied to all sensors. Atmospheric correction was initially based on the ATCOR algorithm (Brazile et al. 2008) for ATSR and MERIS, by adapting the wide field of view of both sensors for this project. However, the final version of the processing chain was based on simpler atmospheric correction to improve process performance. Water, cloud snow and cloud shadow masks were developed to reduce the potential confusions in the BA algorithms, since these covers may present similar spectral characteristics to BA. Particularly challenging was the water mask, since water bodies may be seasonal (flooded areas), and the low radiances of water may be easily mixed up with post-fire char.

\subsection{BA algorithms}

Burned area algorithms were developed based on ten study sites selected from the main ecosystems affected by fire. These algorithms were adapted to VGT and MERIS sensors. Global BA algorithms are particularly challenging, as fire detection is affected by a wide range of factors: pre-fire conditions, burn severity, burn size and regeneration capacity of affected ecosystems (Bastarrika et al. 2011a; Giglio et al. 2009). The VGT algorithm was developed by the Instituto Superior de Agronomía (Pereira et al. 2014) and it is based on multitemporal trend analysis of near infrared reflectance. The process applies robust temporal filters to reduce the impact of instability of the time series, and provides scores of automatically detected changes to select those most likely connected to actual burnings. Initially the algorithm was also tested with ATSR data, but since the temporal resolution of this sensor is lower than VGT, the quality of outputs was considerably lower, and therefore it was decided to focus the global processing on VGT datasets.

The MERIS algorithm was developed from a hybrid two-phase approach, and took into account temporal changes of near infrared reflectance, as well as active fire detections from MODIS thermal channels. The algorithm is regionally adapted, as it estimates threshold values from cumulative distribution functions for both the seed and the region-growing phase (Alonso-Canas and Chuvieco 2014). 
The final step was the merging of VGT and MERIS results into a single BA product. This merging was based on confidence levels derived from each sensor results, using a sample of the reference datasets.

A Round-Robin exercise was conducted between October, 2011 and January 2012, in which all available BA algorithms for VGT and MERIS images were tested. The results were compared using a set of statistical metrics. The goal of this exercise was to select the best performing algorithm for global production of burned area maps. The exercise was open to public participation. Once the final algorithms were selected, they were implemented in the global processing chain. For the current phase 1 of the fire_cci project, three global years have been processed (2006 to 2008).

\subsection{Validation}

Validation of the BA product was carried out by comparing BA outputs with reference fire perimeters generated from Landsat-TM/ETM+ multitemporal images. A standard protocol based on the CEOS LPV recommendations (http://lpvs.gsfc.nasa.gov). was generated and agreed between the internal validation teams to extract fire perimeters from Landsat data, based on a semi-automatic algorithm (Bastarrika et al. 2011b). Two samples of reference sites were obtained, one to measure the spatial variation of accuracy using 100 Landsat pairs acquired in 2008 (global validation), and the other one aiming to measure the temporal stability using a temporal series of Landsat scenes (one each year, whenever available in the Landsat archive) for ten representative study sites (temporal validation) (Figure 3). A total of 242 Landsat pairs were processed, including more than 147.000 burn patches and more than $126.000 \mathrm{~km}^{2}$ of burned area.

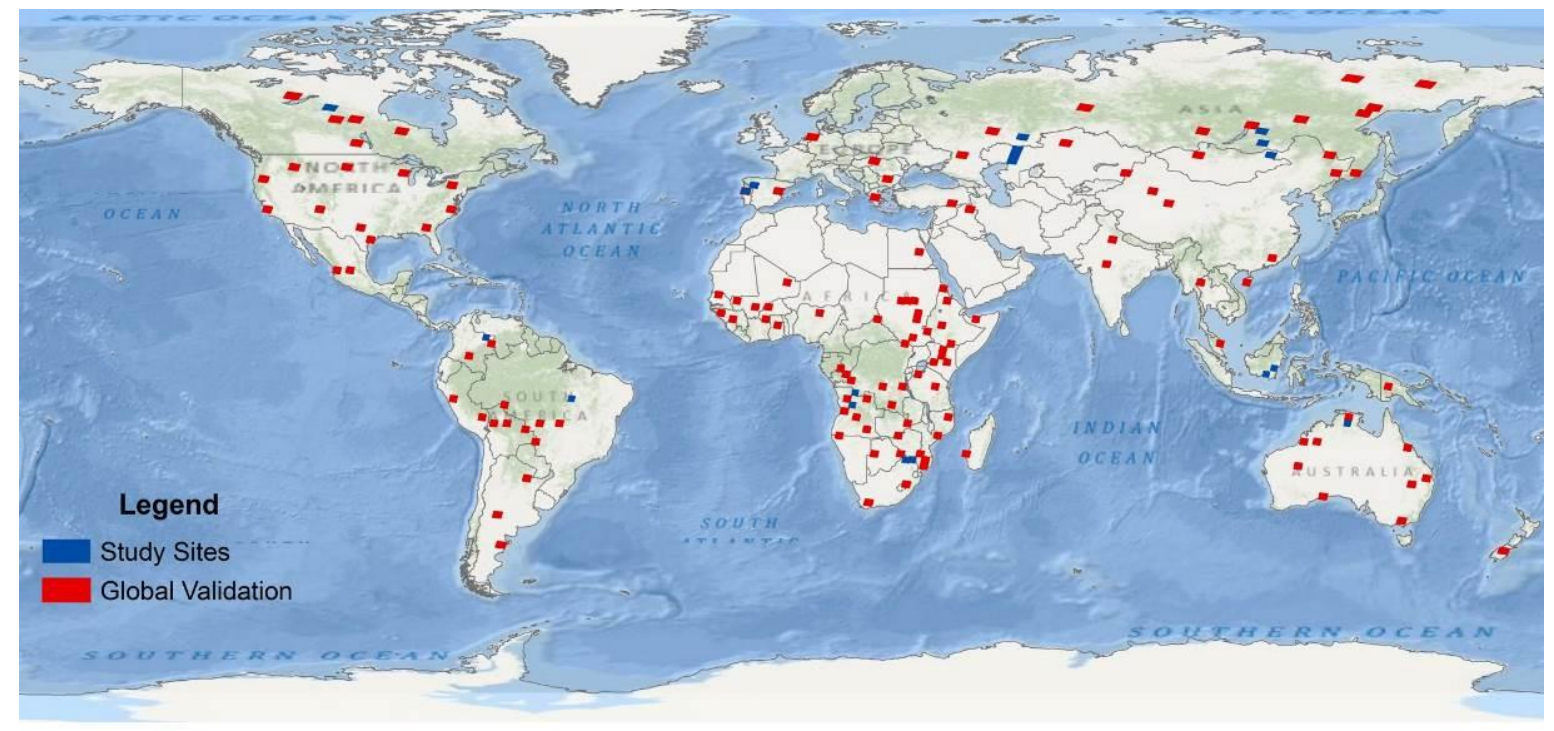

Figure 3. Location of validation sites for the fire_cci project

Validation was based on a fuzzy error matrix and covered three aspects: global accuracy (closeness to the true burned area), error balance (equilibrium between omission and commission errors) and temporal stability (temporal consistency of accuracy). Specific methods to tackle these three aspects were developed (Padilla et al. 2014a; Padilla et al. 2014b).

\subsection{Intercomparison}

The intercomparison analysis was based on comparing the total burned area for the fire_cci products and existing global BA products (Geoland, Globcarbon, GFED3 and MCD45) for each of the three years processed. Correlation analysis was also calculated between our results and existing products considering different ecoregions (those used by the GFED database: Giglio et al. 2010). 


\section{Results}

Global datasets from 2006 to 2008 have been generated and are currently being assessed by climate modellers. In terms of sensors outputs, VGT identified less BA area than MERIS, particularly in tropical regions, as we can notice in Figure 4, and higher values in temperate regions, mainly in agricultural areas.

From preliminary validation, MERIS provides much higher accuracy than VGT, both when comparing with our validation sample and with existing BA products. The merged product showed an intermediate estimation of BA, higher than VGT but still lower than MERIS and other existing BA products (table 1).

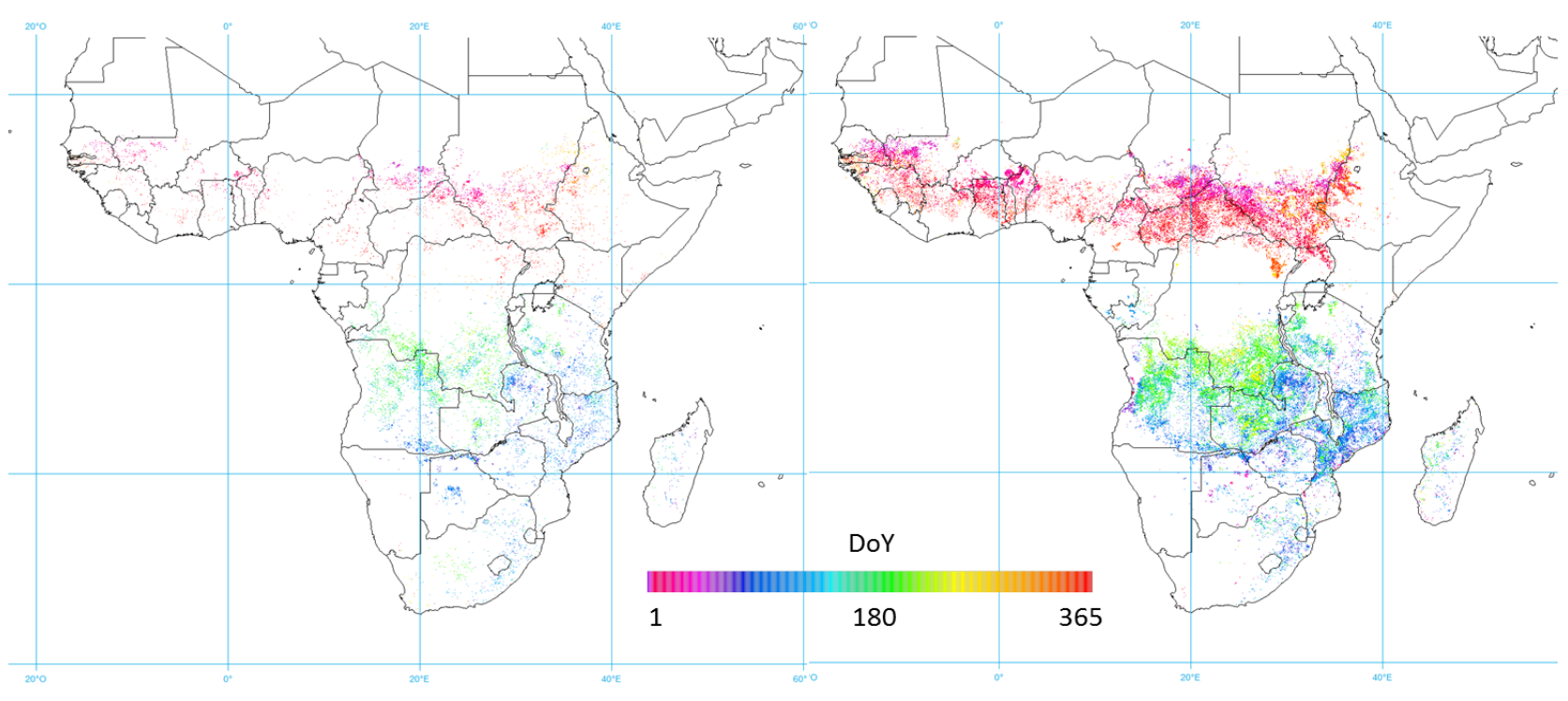

Figure 4. Date of Year (DoY) of Burned Detection from VGT (left) and MERIS (right) over the African continent (2008)

Table 1. Total Burned Area estimated by different global products (sq $\mathrm{km}$ )

\begin{tabular}{|r|r|r|r|r|r|}
\hline & GFED & VGT & MERIS & MERGED & MCD45 \\
\hline 2006 & 3418690 & 2374032 & 3650268 & 2853270 & 3372924 \\
\hline 2007 & 3661888 & 2239012 & 3772086 & 2817410 & 3522453 \\
\hline 2008 & 3296434 & 2228610 & 3623277 & 2687650 & 3307390 \\
\hline
\end{tabular}

In terms of spatial variability, Figure 5 shows the estimated burned area from MERIS BA algorithm. The most extensive burnings occur in the Tropical regions, particularly in the African continent and, with less severity, in the Northern regions of Australia, Central Brazil, Venezuelan and Colombian Llanos, and SE Asia. A second belt of burned regions is noticeable in the temperate grasslands and croplands of central Asia, and SE USA. The boreal forest of Russia and Canada have also a substantial role in global biomass burnings. 


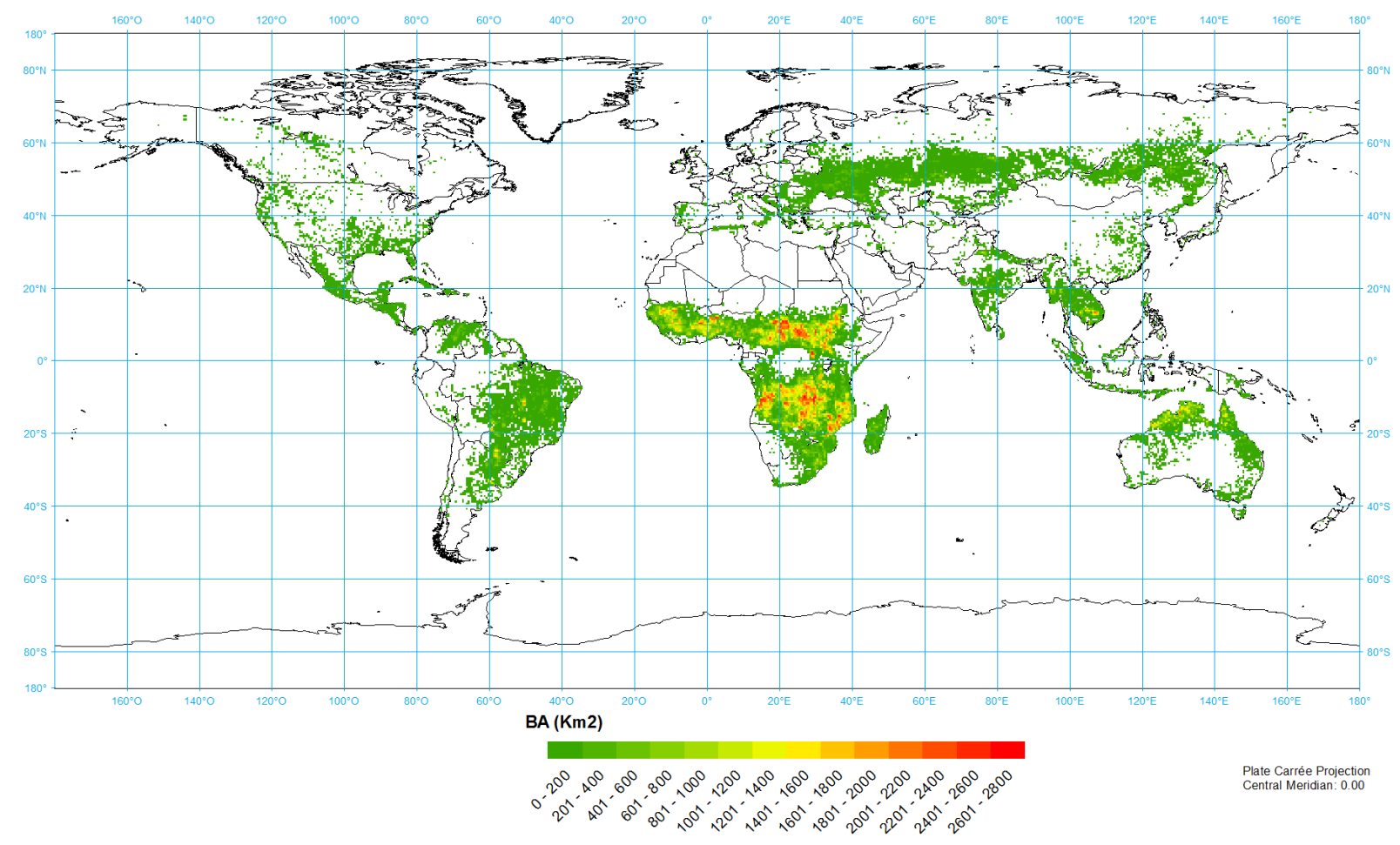

Figure 5. Burned Area estimated from MERIS (2008)

Finally, in terms of estimations produced by our product and other existing global BA products, Figure 6 includes scattergraphs that show the estimated BA in different ecoregions and products. The geographical units were defined by the Global Fire Emissions Database (GFED: Giglio et al. 2010), which is a widely-used information source for burned area information, based on MODIS data. Our MERIS product has very high correlations with GFED, with a tendency of around $10 \%$ to overestimation. Comparing with the standard MODIS BA product (MCD45), the results are similar in terms of trends, although in this case the tendency is towards underestimation.
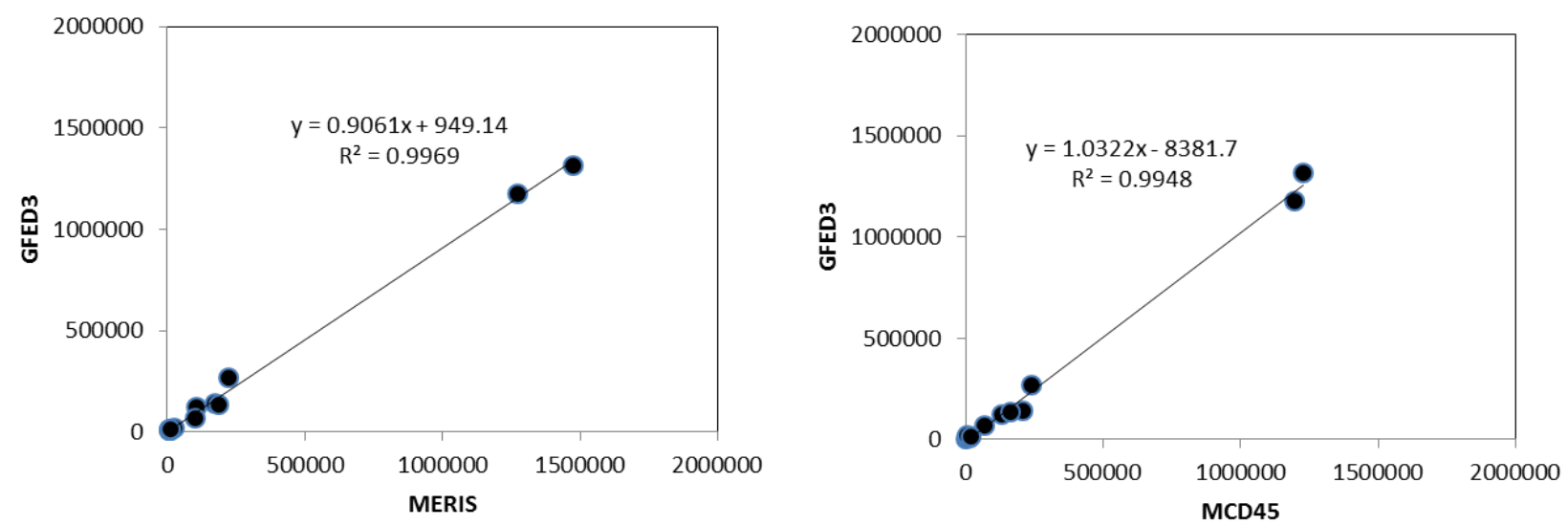

Figure 6. Correlations of BA estimations between MERIS, MCD45 and the GFED in different ecoregions (2008) 


\section{Conclusions}

This paper has presented the first results of the fire_cci project, which aims to map global burned areas from European sensors. Results are currently in the validation stage, but preliminary assessments show good correspondence between our estimations and existing BA products. A climate assessment report to measure the performance of our product as input to existing carbon and atmospheric models is also under development.

\section{Acknowledgements}

This work has been performed within the ESA CCI program (http://www.esa-cci.org/), under the Fire Disturbance project contract.

\section{References}

Alonso-Canas I, Chuvieco E (2014) Global Burned Area Mapping from ENVISAT-MERIS data Remote Sensing of Environment (submitted).

Arino O, Gross D, Ranera F, Bourg L, Leroy M, Bicheron P, Latham J, Di Gregorio A, Brockman C, Witt R (2007) GlobCover: ESA service for global land cover from MERIS. 'IGARSS Symposium' pp. 23-28: Barcelona.

Bastarrika A, Chuvieco E, Martin MP (2011a) Automatic Burned Land Mapping From MODIS Time Series Images: Assessment in Mediterranean Ecosystems. IEEE Transactions on Geoscience and Remote Sensing 49, 3401-3413.

Bastarrika A, Chuvieco E, Martín MP (2011b) Mapping burned areas from Landsat TM/ETM+ data with a two-phase algorithm: balancing omission and commission errors. Remote Sensing of Environment 115, 1003-1012.

Bowman DMJS, Balch JK, Artaxo P, Bond WJ, Carlson JM, Cochrane MA, D'Antonio CM, DeFries RS, Doyle JC, Harrison SP, Johnston FH, Keeley JE, Krawchuk MA, Kull CA, Marston JB, Moritz MA, Prentice IC, Roos C, Scott A, Swetnam T, Van der Werf G, Pyne SJ (2009) Fire in the Earth system. Science 324, 481-484.

Brazile J, Richter R, Schlapfer D, Schaepman ME, Itten KI (2008) Cluster versus grid for operational MODTRAN-based look generation of ATCOR's up tables. Parallel Computing 34, 32-46.

Chuvieco E (2008) Satellite observation of biomass burning: implications in global change research. In 'Earth Observation and Global Change'. (Ed. E Chuvieco) pp. 109-142. (Springer: New York)

Chuvieco E, Aguado I, Yebra M, Nieto H, Salas J, Martín P, Vilar L, Martínez J, Martín S, Ibarra P, de la Riva J, Baeza J, Rodríguez F, Molina JR, Herrera MA, Zamora R (2010) Development of a framework for fire risk assessment using remote sensing and geographic information system technologies. Ecological Modelling 221, 46-58.

Giglio L, Loboda T, Roy DP, Quayle B, Justice CO (2009) An active-fire based burned area mapping algorithm for the MODIS sensor. Remote Sensing of Environment 113, 408-420.

Giglio L, Randerson JT, van der Werf GR, Kasibhatla PS, Collatz GJ, Morton DC, DeFries RS (2010) Assessing variability and long-term trends in burned area by merging multiple satellite fire products. Biogeosciences Discuss. 7, 1171-1186, doi:10.5194/bg-7-1171-2010,.

Mouillot F, Schultz MG, Yue C, Cadule P, Tansey K, Ciais P, Chuvieco E (2014) Ten years of global burned area products from spaceborne remote sensing-A review: Analysis of user needs and recommendations for future developments. International Journal of Applied Earth Observation and Geoinformation 26, 64-79.

Padilla M, Stehman SV, Chuvieco E (2014a) Validation of the 2008 MODIS-MCD45 global burned area product using stratified random sampling. Remote Sensing of Environment 144, 187-196. 
Padilla M, Stehman SV, Litago J, Chuvieco E (2014b) Assessing the Temporal Stability of the Accuracy of a Time Series of Burned Area Products. Remote Sensing 6, 2050-2068.

Pereira JM, Mota B, Calado T, Alonso IJ, Oliva P, González-Alonso F (2014) 'ESA CCI ECV Fire Disturbance - Algorithm Theoretical Basis Document - Volume II - BA Algorithm Development.' ESA Fire-CCI project.

Plummer S (2009) 'The ESA Climate Change Initiative. Description.' (ESA-ESRIN: Frascati)

Tansey K, Grégoire JM, Defourny P, Leigh R, Peckel JF, Bogaert EV, Bartholome JE (2008) A new, global, multi-annual (2000-2007) burnt area product at $1 \mathrm{~km}$ resolution. Geophysical Research Letters 35, L01401, doi:10.1029/2007GL03156.

Thonicke K, Spessa A, Prentice IC, Harrison SP, Dong L, Carmona-Moreno C (2010) The influence of vegetation, fire spread and fire behaviour on biomass burning and trace gas emissions: results from a process-based model. Biogeosciences 7, 1991-2011.

van der Werf GR, Randerson JT, Giglio L, Collatz G, Mu M, Kasibhatla PS, Morton DC, DeFries RS, Jin Y, van Leeuwen TT (2010) Global fire emissions and the contribution of deforestation, savanna, forest, agricultural, and peat fires (1997-2009). Atmospheric Chemistry and Physics 10, $11707-$ 11735 . 